\title{
A Study of the Effect of Macroeconomic Variables on Stock Market: Saudi Perspective
}

\author{
Durga Prasad Samontaray ${ }^{1}$, Sultan Nugali ${ }^{2} \&$ Bokkasam Sasidhar ${ }^{3}$ \\ ${ }^{1}$ Department of Finance, College of Business Administration, King Saud University, Riyadh, Saudi Arabia \\ ${ }^{2}$ Fixed Income and Money Market, Asset Management Department, Saudi Fransi Capital, Riyadh, Saudi Arabia \\ ${ }^{3}$ Department of Quantitative Analysis, College of Business Administration, King Saud University, Riyadh, Saudi \\ Arabia \\ Correspondence: Dr. Durga Prasad Samontaray, Associate Professor, Department of Finance, College of Business \\ Administration, King Saud University, Riyadh, Saudi Arabia. Te: 966-55-822-1973. E-mail: \\ dsamontaray@ksu.edu.sa,drdpsray@gmail.com
}

Received: May 31, 2014

Accepted: September 4, $2014 \quad$ Online Published: September 26, 2014

doi:10.5430/ijfr.v5n4p120

URL: http://dx.doi.org/10.5430/ijfr.v5n4p120

This paper is supported by the Research Center at the College of Business Administration and the Deanship of Scientific Research at King Saud University, Riyadh.

\begin{abstract}
As we know investment in the Saudi stock market (TASI) is gaining popularity particularly since 2001 (Report of Aljazira Capital - 2010), it is important to know the impact of different macro-economic variables on the returns of the Saudi stock market. In this regard along with an extensive literature review we also referred specific recent few important studies which considered the Saudi stock return as a dependent variable and other economic factors as the independent variables [Kalyanaraman and Al-Tuwajri (2014), Arouri and Rault (2010) and Onour (2008)]. This paper examines the three important factors influencing the returns in the Saudi Stock Exchange (TASI) based on the macroeconomic variables of Saudi Economy. The dependent variable taken here is the Saudi index that is TADAWUL All Stock Index (TASI) and the three independent variables considered for our study here are the Oil WTI, Saudi Exports and the PE Ratio. Correlation analysis revealed that Saudi Exports and the PE Ratio were found to be highly correlated with TASI at $1 \%$ level of significance whereas Oil WTI and TASI are significantly correlated at $5 \%$ level. Step-wise regression analysis of the data revealed that the multiple regression models is significant at $1 \%$ level and the variable PE Ratio was the most important determinant of TASI followed by Oil WTI and Saudi Exports. Further the three independent variables explain about $93 \%$ of variation in the TASI Last Price.
\end{abstract}

Keywords: TASI, oil WTI, PE ratio, Saudi export, correlation, regression

\section{Introduction}

Stock market is an important part of the economy of a country. The stock market plays a pivotal role in the growth of the industry and commerce of the country that eventually affects the economy of the country to great extent. Stock market is seen as a very significant component of the financial sector of any economy. Moreover it is seen as a source of distribution of wealth and mobilization of capital. Saudi stock market has 161 companies listed currently compared to 76 companies listed in 2001. With the establishment of Capital market Authority (CMA), the investors 'confidence have been strengthened and in return the Saudi capital market has shown the market capital representing more than $82 \%$ of 2012 GDP.

The Saudi stock exchange (TASI) has been considered as a proxy of the Saudi market and used to obtain a measure of market price movement of Saudi securities. Majority of studies have examined different markets, whether developed or developing countries. Moreover, certain researches covered emerging markets as well. It is observed that studies on Saudi Arabia covered only one variable of Oil prices and did not examine a mix of macroeconomic data. 
Oil prices are used as a proxy to the Saudi economy because it has a direct influence on the Saudi economy. Price earnings ratio is used as a proxy of attractiveness to investors to invest in TASI. The Saudi trade export is used as a proxy that influences the Saudi balance sheet. Crude oil is the most actively traded commodity and the future contract is considered to be the most liquid forum for crude oil trading. Because of this liquidity and price transparency, the contract is used as a principal international pricing benchmark. Hence Oil WTI has been considered as the third influencing variable.

The relationship between the dependent variable (TASI) and independent variables (OIL WTI, Saudi Export and PE Ratio) is depicted in Diagram 1.

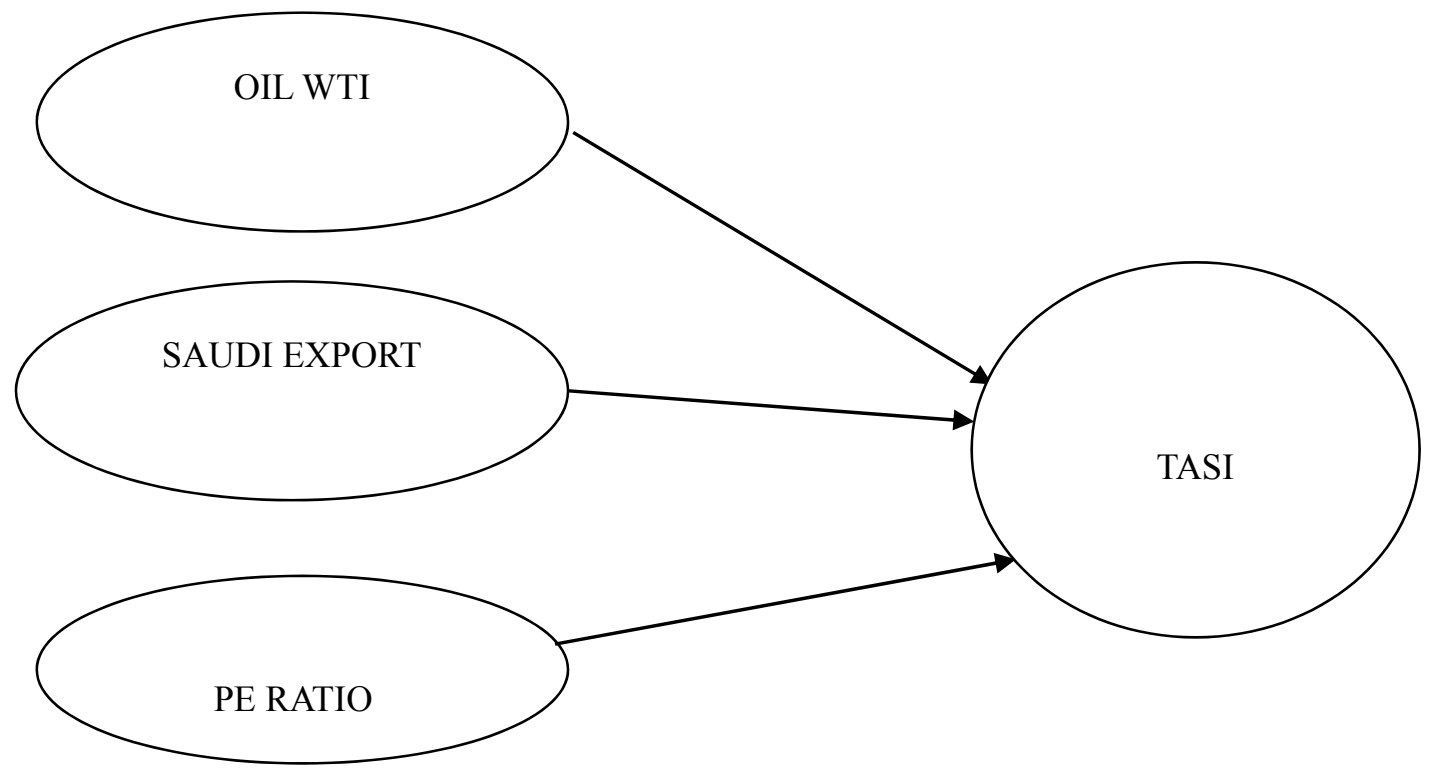

Diagram 1. Schematic diagram of the theoretical framework

As we know that the equity market all over the globe is volatile, more in the developing world as compared to the developed economies, therefore it is very important to show the proposed and existing investors the relationship between the macro economic variables with the particular equity market. As the Saudi economy is highly influencing the GCC market and the Saudi equity market is growing very fast (as per the TADAWUL website), therefore it is pertinent to consider the influence of the independent variables like OIL WTI, Saudi Export and PE Ratio, with the dependent variable the Tadawul all stock Index (TASI).

This study provides an insight about the positive relationship between the said independent variables with the dependent variable. It also suggests that two of the independent variables viz., PE Ratio and OIL WTI, have significant influence on TASI. The model provides a mathematical relation for predicting TASI for the possible values of the independent variables. The investors may note that as PE Ratio and OIL WTI improves, the TASI will improve significantly and vice versa.

\section{Present Body of Knowledge from the Existing Review of Literature}

\subsection{Existing Review of Literature}

Abedallat \& Shabib (2012), studied the impact of macroeconomic indicators like change in investment and gross domestic product (GDP) as the independent variables and the movement of Amman Stock Exchange index as dependent variable for the data period of 1990- 2009. For the analysis of the above relationship they used the multiple regressions. They found a relationship between the two macroeconomic indicators (the investment and GDP) and the Amman Stock Exchange index, and also between each of them separately and the stock index, which means that the movement of prices in the Amman Stock Exchange affected by the movement of these two variables, and there is the effect of both variables on the movement of Amman Stock Exchange index. Further they found the impact of the change in investments was greater than the impact of change in GDP on the Amman Stock Exchange index. 
Anlas (2012) has studied the effects of changes in foreign exchange rates on ISE - 100 Index (Istanbul Stock Exchange Composite Index), taking the monthly data for a period of more than ten years stating from January 1999 to November 2011. By applying the techniques of time series analysis he found that changes in domestic U.S. Dollar and Canadian dollar are positively related to changes in ISE 100 while fluctuations in domestic interest rates and Saudi Arabia Riyal have a negative impact on the index. He also discussed the implications of these results on the portfolio and traditional approaches to estimation of returns.

Arouri and Rault (2010) made an interesting study of the relationship of oil prices and stock market and tried to explore what drives what in the gulf corporation council (GCC) countries. They applied the recent bootstrap panel cointegration techniques and seemingly unrelated regression (SUR) methods to investigate the existence of a long-run relationship between oil prices and Gulf Corporation Countries (GCC) stock markets. They have used two different (weekly and monthly) datasets covering respectively the periods from 7 June 2005 to 21 October 2008, and from January 1996 to December 2007, and their investigation showed that there is evidence for cointegration of oil prices and stock markets in GCC countries, while the SUR results indicate that oil price increases have a positive impact on stock prices in all GCC countries except in Saudi Arabia.

Onour (2008) studied the changes in oil prices influence on the observable factors in gulf corporation council (GCC) countries; he found unobservable speculative factors drive the short-term stock market returns in Saudi and Bahrain markets and for other GCC markets, such as Dubai, Abu-Dhabi, and Muscat, both the oil price uncertainty and unobservable speculative factors work hand in hand, though in opposite directions, to influence the stock prices. However, in the long term, he found only oil price changes prevail as a determinant of GCC stock prices. He defined long term as the period of time required for the effect of oil price changes to transmit its influence to major macroeconomic indicators that influence the profitability of firms traded in GCC stock markets.

FAMA (1981 \& 1990), FAMA and French(1989), Ferson and Harvey(1991),all these studies in general found out empirically the significant relationship between stock market returns and change in macroeconomic variables, such as inflation, interest rate changes, yield curve ,money supply and industrial production. Schwert (1990), studied the indexes of US stock prices from the year 1802 to the year 1987. For this purpose he used the data of NYSE, Dow Jones, S\&P, CRSP, AMEX. Splicing together the best indexes give monthly data from the year 1802 to 1987 and daily data from 1885 to 1987.

Acikalin, Aktas and Unal (2008) investgated that the relationship between stocks return in the Istanbul Stock Exchange (ISE) and the macro economic variables of the Turkish economy. They took the quarterly data sets and applied the cointegration tests and vector error correlation method (VECM), and found that long term stable relationship between ISE and four macroeconomic variables such as GDP, exchange rate, interest rate, and current account balance by applying the causality tests, they found unidirectional relationships between macro indicators and ISE index.

Subeniotis, Papadopoulos, Tampakpodis, and Tampakpoudi (2011) used the panel data analysi and investigated the relationship between the stock market price indices for 12 European countries (common currency Euro) and four key variables (market capitalization, industrial production, the economic sentiment indicators and inflation) from the period of 2000 to 2005. They found strong effect of the first three factors, while inflation has a negative but statistically insignificant. The market capitalization and the economic sentiment indicators affect the stock markets positively. They also found a significant convergence of the 12 European Union countries in the long run.

Chen (2008) investigated whether macroeconomic variables can predict recession in the stock market, series such as interest rate spreads inflation rates, money stocks, aggregate output, and unemployment rates are evaluated individually, the evidence from monthly data on S\&P500 price index suggests that among the macroeconomic variables that are considered, yield curve spreads and inflation rates are the most useful predictors of recessions in the U.S stock market according to in sample out of sample forecasting performance.

Kalyanaraman and Al-Tuwajri (2014) examined the existence of long run relationship among five macroeconomic variables of CPI, industrial output, money supply, exchange rate, oil price along with proxy of S\&P 500 and the TASI (Saudi All stock index). They used the monthly data from 1994 to 2013 and applied the time series analysis. They found an existence of long run relationship among the five variables and all the five variables put an impact on stock price whereas S\&P 500 index does not impact Saudi stock prices. Vector error correlation model shows the presence of long run causality from the explanatory variables to the stock prices. Short run causality test found a two way causality between stock prices and oil prices they also found that the industrial production shocks pushes up the stock prices while consumer price index shocks pulls the stock price down. 
Singh, Tripathi, and Parashar (2013) examined the primary factors those are responsible for affecting the index (NIFTY) in National Stock Index in India. They took Exchange rate, IIP, WPI as the independent variable and applied regression analysis and found that IIP, exchange rate and WPI influences the stock prices.

Bahmani and Sohrabian (1992) studied the causal relationship between S\&P500 and effective exchange rate of dollar in short period of time, however co integration analysis failed to identify any long relationship between the two variables.

Abdulla and Murinde (1997) investigated the intersection between exchange rates and stock prices of emerging financial markets like Philippines, Korea, Pakistan, India, the results obtained found that results show unidirectional granger casualty from exchange rates to stock prices in all sample countries except for the Philippines where they found the stock prices lead the exchange rate.

\subsection{Present Body of Knowledge from the Review of Literature and Research Gap}

A lot of studies have been taken place across the globe, as well as the GCC market and also specific studies have been taken place from Saudi perspective. The above review also shows that both long term as well as short term impact has been studied. All the studies above have considered stock return as the dependent variables and the various macroeconomic independent variables considered are: the investment and GDP (Abedallat \& Shabib, 2012), changes in domestic U.S. Dollar and Canadian dollar, fluctuations in domestic interest rates and Saudi Arabia Riyal (Anlas, 2012), oil prices (Arouri \& Rault, 2010 and Onour, 2008), change in macroeconomic variables, such as inflation, interest rate changes, yield curve, money supply and industrial production (FAMA, $1981 \&$ 1990, and FAMA \& French, 1989, and Ferson \& Harvey, 1991).

GDP, exchange rate, interest rate, and current account balance (Acikalin, Aktas \& Unal, 2008), market capitalization, industrial production, the economic sentiment indicators and inflation (Subeniotis, Papadopoulos, Tampakpodis, and Tampakpoudi, 2011), yield curve spreads and inflation rates (Chen, 2008), CPI, industrial output, money supply, exchange rate, oil price (Kalyanaraman and Al-Tuwajri, 2014), Exchange rate, IIP, WPI, (Singh, Tripathi, \& Parashar, 2013), effective exchange rate of dollar in short period of time (Bahmani \& Sohrabian, 1992), and exchange rates (Abdulla \& Murinde, 1997).

After going through the above extensive review of existing literatures we tried to enrich the context of research by adding two new macroeconomic variables of Saudi Export, P/E Ratio and maintain one existing variable of Oil WTI. Therefore here our dependent variable became the Saudi Stock return and three independent variables of Oil WTI, Saudi Export and P/E Ratio.

\section{Methodology and Theoretical Framework}

\subsection{Objective of Study}

The objective of the study is to investigate the relationship between Saudi Index (TASI) and three macroeconomic variables: Oil WTI, Saudi Exports and Price Earnings ratio (PE Ratio). Further, the study aims at developing a mathematical model for estimating the TASI for the known values of the three macroeconomic variables.

\subsection{Theoretical Framework \& Data Definitions}

In this research, TASI is the dependent variable, the variance of which is to be explained by the three independent variables, OIL WTI, Saudi Export and PE Ratio.

The Saudi stock exchange (TASI) has been considered as a proxy of the Saudi market and used to obtain a measure of market price movement of Saudi securities. Since this index is comprehensive, to address the objective of this research, the movements in TASI provide the changes in Saudi market (www.tadawul.com.sa).

Our first independent variable as Oil WTI (West Texas Intermediate), it is also known as Texas light sweet, which is a grade of crude oil used as a benchmark in oil pricing. This grade is described as light because of its relatively low density, and sweet because of its low sulfur content. Oil WTI is the underlying commodity of Chicago Mercantile Exchange's oil futures contracts. Other important oil markers include the Dubai Crude, Oman Crude, and the OPEC Reference Basket (Vassiliou, 2009, and Wikipedia).

The second independent variable we selected is Saudi exports. Like any economy in the world, Saudi economy (GDP) also gets hugely affected by the Saudi exports. Similarly the stock exchanges also get affected by the exports of a particular country. As per a survey report of Trading Economics the Saudi Arabian exports averaged 223503.06 Million SAR from 1968 until 2013. The Exports in Saudi Arabia is reported by the Saudi Arabian Monetary Agency 
(SAMA). Therefore we have decided to make this as an important variable to be studied to find its influence on the Saudi stock exchange (trading economics, Saudi Arabia).

The third independent variable for our study is the P/E ratio of the trading firms in the exchange. This is the ratio of market price of the stock to the expected earning of the stock. This ratio is often referred as the earnings multiple also.

\subsection{Hypotheses}

The following hypotheses were developed and proposed from the theoretical framework:

1. TASI and OIL WTI are positively correlated

2. TASI and SAUDI EXPORT are positively correlated

3. TASI and PE RATIO are positively correlated

4. There is significant dependence between OIL WTI and TASI

5. There is significant dependence between SAUDI EXPORT and TASI

6. There is significant dependence between PE RATIO and TASI

\subsection{Data Collection}

The data has been collected for a time span of 10 years for this study which is from December 2003 to December 2013 using a monthly data to portray a larger view of the relationship. After using the data filtration criteria the data covers 129 monthly observations for each variables. The data regarding TASI and the sectors have been extracted from Tadawul (the official website of Saudi Stock Exchange) web site (www.tadawul.com.sa) and for the other variables from Bloomberg terminal.

\section{Data Analysis}

A time span of 10 years has been chosen for this study from December 2003 to December 2013 using a monthly data to have a larger view of the relationship. The data covers 129 monthly observations. The data collected were analyzed using SPSS Statistics 20.

Table 1 presents a summary of descriptive statistics of all the variables considered.

Table 1. Descriptive statistics

\begin{tabular}{ccccccc}
\hline Variables & Mean & Std.Deviation & $\begin{array}{c}\text { Coefficient of } \\
\text { Variation (\%) }\end{array}$ & Maximum & Minimum & Range \\
\hline TASI & $7,702.90$ & $3,169.50$ & 41.15 & $19,502.65$ & $2,423.07$ & $17,079.58$ \\
\hline OIL WTI & 72.99 & 25.08 & 34.36 & 140.00 & 25.80 & 114.20 \\
\hline Saudi Export & 125.56 & 215.81 & 171.88 & $1,517.00$ & 16.75 & $1,500.25$ \\
\hline PE Ratio & 30.57 & 27.10 & 88.65 & 123.90 & 8.90 & 115.00 \\
\hline Observations & 129 & 129 & 129 & 129 & 129 & 129 \\
\hline
\end{tabular}

The coefficients of variation for the variables reveal that the variability is quite high in all the variables.

In order to investigate the relationship between Saudi Index (TASI) and three macroeconomic variables, correlation analysis was carried out. The results of the analysis are presented in Table 2.

Table 2. Correlation matrix

\begin{tabular}{llrrr}
\hline & & \multicolumn{1}{c}{ Saudi Export } & OIL WTI & \multicolumn{1}{c}{ PE Ratio } \\
\hline Last Price & Pearson & $.794^{* *}$ & $.192^{*}$ & $.842^{* *}$ \\
(TASI) & Correlation & & & \\
& Sig. (2-tailed) & .000 & .029 & .000 \\
& $\mathrm{~N}$ & 129 & 129 & 129 \\
\hline
\end{tabular}

**Correlation is significant at the 0.01 level (2-tailed).

*Correlation is significant at the 0.05 level (2-tailed). 
The table shows the correlation matrix of stock exchange index and macroeconomic variables, correlation among all variables have been reported. The results reveal that TASI and Saudi Exports as well as TASI and the PE Ratio are highly positively correlated at $1 \%$ level of significance whereas Oil WTI and TASI are significantly positively correlated at 5\% level.

\subsection{Regression Analysis}

In order to establish mathematical relation between the dependent and independent variables, step-wise multiple regression analysis is carried out. This technique is especially useful for sifting through potential independent variables and for fine-tuning the model by adding significant variables into the model.

A stepwise multiple regression was conducted to evaluate whether the variables PE Ratio, OIL WTI and PE Ratio were necessary to predict last price (TASI). At step 1 of the analysis PE Ratio entered into the regression equation and was significantly related to the TASI $(\mathrm{p}<0.001)$. The multiple correlation coefficient was 0.842 , indicating approximately $70.7 \%$ of the variance of the TASI could be accounted for by PE Ratio. At step 2 of the analysis OIL WTI entered into the regression equation and was also significantly related to the TASI $(p<0.001)$. The multiple correlation coefficient was 0.955 , indicating approximately $91.0 \%$ of the variance of the TASI could be accounted for by PE Ratio and OIL WTI. At step 3 of the analysis Saudi Export entered into the regression equation and was significantly related to the TASI $(p<0.001)$. The multiple correlation coefficient was 0.964 , indicating approximately $92.8 \%$ of the variance of the TASI could be accounted for by PE Ratio, OIL WTI and Saudi Exports. The model summary and the significance of the models are presented in Tables 3 and 4.

Table 3. Model summary

\begin{tabular}{lrrrr}
\hline Model & R & R Square & \multicolumn{1}{c}{$\begin{array}{c}\text { Adjusted R } \\
\text { Square }\end{array}$} & $\begin{array}{c}\text { Std. Error of the } \\
\text { Estimate }\end{array}$ \\
\hline 1 & $.842^{\mathrm{a}}$ & .709 & .707 & 1735.8487452 \\
2 & $.955^{\mathrm{b}}$ & .912 & .910 & 960.3354312 \\
3 & $.964^{\mathrm{c}}$ & .929 & .928 & 861.7869206 \\
\hline
\end{tabular}

a. Predictors: (Constant), PE Ratio

b. Predictors: (Constant), PE Ratio, OIL WTI

c. Predictors: (Constant), PE Ratio, OIL WTI, Saudi Export

Table 4. ANOVA $^{\mathrm{a}}$

\begin{tabular}{rlrrrcr}
\hline Model & & Sum of Squares & df & Mean Square & F & \multicolumn{1}{l}{ Sig. } \\
\hline \multirow{2}{*}{1} & Regression & 932135800.094 & 1 & 932135800.094 & 309.354 & $.000^{\mathrm{b}}$ \\
& Residual & 382672700.009 & 127 & 3013170.866 & & \\
& Total & 1314808500.103 & 128 & & & \\
& Regression & 1198605738.416 & 2 & 599302869.208 & 649.831 & $.000^{\mathrm{c}}$ \\
& Residual & 116202761.687 & 126 & 922244.140 & & \\
& Total & 1314808500.103 & 128 & & & \\
& Regression & 1221973913.040 & 3 & 407324637.680 & 548.455 & $.000^{\text {d }}$ \\
& Residual & 92834587.063 & 125 & 742676.697 & & \\
& Total & 1314808500.103 & 128 & & & \\
\hline
\end{tabular}
a. Dependent Variable: Last Price
b. Predictors: (Constant), PE Ratio
c. Predictors: (Constant), PE Ratio, OIL WTI
d. Predictors: (Constant), PE Ratio, OIL WTI, Saudi Export 
Table 5. Coefficients ${ }^{\mathrm{a}}$

\begin{tabular}{|c|c|c|c|c|c|c|}
\hline \multirow[t]{2}{*}{ Model } & & \multicolumn{2}{|c|}{ Unstandardized Coefficients } & $\begin{array}{l}\text { Standardized } \\
\text { Coefficients }\end{array}$ & \multirow[t]{2}{*}{$\mathrm{t}$} & \multirow[t]{2}{*}{ Sig. } \\
\hline & & B & Std. Error & Beta & & \\
\hline \multirow{3}{*}{1} & (Constant) & 4644.987 & 230.899 & & 20.117 & .000 \\
\hline & PE Ratio & 99.582 & 5.662 & .842 & 17.588 & .000 \\
\hline & (Constant) & -180.136 & 311.280 & & -.579 & .564 \\
\hline \multirow[t]{3}{*}{2} & PE Ratio & 115.394 & 3.268 & .976 & 35.315 & .000 \\
\hline & OIL WTI & 59.929 & 3.526 & .470 & 16.998 & .000 \\
\hline & (Constant) & 195.191 & 287.239 & & .680 & .498 \\
\hline \multirow{3}{*}{3} & PE Ratio & 90.878 & 5.263 & .768 & 17.267 & .000 \\
\hline & OIL WTI & 58.772 & 3.171 & .461 & 18.537 & .000 \\
\hline & Saudi Export & 3.594 & .641 & .244 & 5.609 & .000 \\
\hline
\end{tabular}

a. Dependent Variable: Last Price

The multiple regression equation for predicting the Last price using the variables PE Ratio, OIL WTI, Saudi Export can be arrived at using the Table 5, the table of coefficients. The multiple regression equation is as follows:

$$
y=195.191+90.878(\text { PE Ratio })+58.772(\text { OIL WTI })+3.594(\text { Saudi Export })+\varepsilon
$$

\section{Conclusion}

The study confirms that TASI is positively correlated with the three economic variables considered, viz., Oil WTI, Saudi Exports and Price Earnings ratio. Since the three independent variables are significantly correlated with the dependent variable, the step-wise regression confirms the significant importance each of these three variables have, in predicting the TASI. Further it is observed that these three variables explain about $93 \%$ of variation in TASI. Further, the study confirms all the six hypotheses enumerated in 3.3. The mathematical relation for estimating TASI using the three variables enables to predict the TASI value for the given values of the three variables.

This study also further strengthens the findings of previous recent study where the authors found an existence of long-run relationship among the five variables of CPI, Industrial output, money supply, exchange rate and oil prices (Kalyanaraman \& Al-Tuwajri, 2014). This study strengthens the findings of another research where the authors predicted that there is evidence for cointegration of oil prices and stock markets in GCC countries (Arouri \& Rault, 2010) and also a research findings of Positive relationship of ISE 100 with the US Dollars and Canadian Dollars where as the authors in that study found a negative impact of domestic interest rates and change in saud Arabian Riyal on the returns of ISE 100 (Anlas, 2012).

\section{References}

Abdalla, I.S.A., \& Murinde, V. (1997). Exchange rate and stock price interactions in emerging financial markets: Evidence on India, Korea, Pakistan, and Philippines. Applied Financial Economics, 7, 25-35. http://dx.doi.org/10.1080/096031097333826

Acikalin, S., Aktas, R., \& Unal, S. (2008). Relationships between stock markets and macroeconomic variables: an empirical analysis of the istanbul Stock Exchange. Investment Management and Financial Innovations, 5(1), 8-16.

Al-Abedallat, A.Z., \& Al-Shabib, D.K. (2012). Impact of the investment and gross domestic product on the Amman Stock Exchange index. Investment Management and Financial Innovations, 9(3), 130-136.

Anlas, T. (2012). The effects of changes in foreign exchange rates on ISE - 100 Index. Journal of Applied Economics and Business Research (JAEBR), 2(1), 34-45.

Arouri, M.E.H., \& Rault, C. (2010). On the Influence of Oil Prices on Stock Markets: Evidence from Panel Analysis in GCC Countries. Economic Research Forum (ERF), Working Paper No. 538, Cairo, Egypt, August - 2010, pp. $1-19$. 
Bahmani, O. M., \& Sohrabian, A. (1992). Stock prices and the effective exchange rate of the dollar. Applied Economics, 24(4), 459-464. http://dx.doi.org/10.1080/00036849200000020

Chen, N. F., Richard, R., \& Ross, S.A. (1986). Economic Forces and the Stock Mrket. Journal of Business, 59, 383-403. http://dx.doi.org/10.1086/296344

Fama, E.F. (1981). Stock returns, real activity, Inflation, and Money. American Economic Review, 71(4), 545-565.

Fama, E.F. (1990, September). Stock returns, expected returns, and real activity. Journal of Finance, 45(4), 1089-1108.

Fama, E.F., \& K.R. French. (1989). Business Conditions and Expected Returns on Stocks and Bonds. Journal of Financial Economics, 25, 23-49. http://dx.doi.org/10.1016/0304-405X(89)90095-0

Ibrahim, M. H. (1999). Macroeconomic Variables and the Malaysian Equity Market a view through rolling subsamples. Journal of economic studies, 30, 6-27. http://dx.doi.org/10.1108/01443580310455241

Kalyanaraman, L., \& Al-Tuwajri, B. (2014). Macroeconomic forces and stock prices: some empirical evidence from Saudi Arabia. International Journal of Financial Research, 5(1), 81-92.

Kumar, Narayan. (2008). On the relationship between stock prices and exchange rates for India. World Scientific, $12(2), 1-12$.

Onour, I.A. (2008). What drives short-term GCC stock market returns? Empirical evidence from fat-tailed distribution. Afro-Asian J. Finance and Accounting, 1(1), 17-25. http://dx.doi.org/10.1504/AAJFA.2008.016888

Schwert, G.W. (1990). Indexes of US Stock Prices from 1802 to 1987. Journal of Business, 63(3), 399-442. http://dx.doi.org/10.1086/296513

Singh, S., Tripathi, L.K., \& Parashar, A. (2013, October). Ä study of impact of macroeconomic variables on profitability of Nifty. Asian Journal of Research in Business Economics and Management, 3(10), 205-216.

Subeniotis, D.N., Papadopoulos, D.L., Tampakpodis, I.A., \& Tampakpoudi, A. (2011). How inflation, market capitalization and the economic sentiment indicator affect the EU - 12 stock markets. European Research Studies, XIV(1), 103-118.

Vassiliou, V. (2009). Historical Dictionary of the Petroleum Industry. Lanham, MD: Scarecrow Press.

www.bloomberg.com

www.damodaran.com

www.en.wikipedia.org/wiki/West_Texas_Intermediate

www.google.com

www.search.epnet.com

www.ssrn.com

www.tadawual.com.sa

www.tradingeconomics.com/saudi-arabia/exports

www.worldbank.org 